\author{
Czesław Machelski \\ Prof. dr hab. inż. \\ Politechnika Wrocławska, Wydział Budownictwa Lądowego i Wodnego, \\ Katedra Mostów i Kolei \\ czeslaw.machelski@pwr.wroc.pl
}

DOI: 10.35117/A_ENG_16_02_01

\title{
The stiffness of bridge structure as performance parameters of communication
}

\begin{abstract}
The stiffness of a bridge structure as a utility parameter of transport constructions Bridge structures, according to the project assumptions, must meet the static-strength requirements included in the service load bearing capacity of a structure. In the case of slender transport structures, an essential condition of usage (deflections) is the stiffness of the structure, which is the subject of the article. In the case of footbridges, their stiffness may be a basic requirement, resulting from the dynamic vulnerability of the structure. The stiffness of an object can be determined on the basis of calculations using a model of a structure. The second method is the measurement of displacements of an object under a service load, as well as during acceptance tests. Examples given in the paper indicate that the rigidity of an object is a universal technical parameter covering different bridge structures. The value $\mathrm{k}$ allows an objective justification of the division of bridge structures into massive and slender constructions.
\end{abstract}

Keywords: Stiffness of bridges; parametric analysis; investigation of displacements.

\section{Introduction}

The term stiffness is often used for the general classification of objects, not only connected with construction. It is the basis of structure division in two groups: prone (openwork) and the massive (monolithic). In buildings with a communication purpose is often used to test the stiffness of their qualification. In highway engineering surfaces are divided on rigid and vulnerable. In the same way we can distinguish ground under the pavement, e.g. on the concrete bridge - rigid, and on the embankment - prone. A similar classification concerns bridges e.g. a rigid are lattice railway facilities and slender suspended footbridges. A good example of this object division are arch bridges containing: brick vaults - a massive and ground-coating corrugated metal - as susceptible.

In material durability, stiffness of the element is defined as the proportion of the force $\mathrm{P}$ to arisen displacements, as in formula

$$
k=\frac{P}{w}[\mathrm{kN} / \mathrm{mm}]
$$

Determined in this way parameter $\mathrm{k}$ is easy to justify, in simple strength cases: compression (pole), stretching (tie), bending (beam), twisting (shaft). In addition, in the case of linear elasticity, it is constant, regardless of the force value, which causes displacement. Also, a simple interpretation of the $\mathrm{k}$ value is to determine the stiffness of the substrate single site Winkler. Whereas the phrase rigidity of the road surface as a layer system is a complicated issue. Pavement and surface models to account the elastic properties of the elastic-plastic are discussed in elaborations [7 - 10]. In case of train surfaces model is formulated differently, as in elaborations [1, 4, 11 - 14]. In case of bridge structures formed from many elements of nature in the spatial arrangement of a large number of degrees of freedom, a simple procedure is needed- proposed in $[5,6]$ with application examples given in elaboration.

Stiffness of bridge is a static feature associated with the changing load position on the roadway object. In practice, it is determined on the basis of the measurements of displace- 
ments built bridges results, in attempts static during acceptance tests [5, 6]. In such studies in appointed stiffness we take into account: the geometry of the design, layout and component stiffness (EI, EA), bonds of support included in the object schema and cooperation with equipment design (e.g. surface). In the design calculations (checking the results of acceptance tests) usually overlooked is the equipment as a part cooperating with the design of moving loads transfer [5].

Stiffness of structure designed for bridge under a movable load exploitation is also defined in dynamic tests. Fig. 1 shows the results of various road facilities. These analysis were done by the way of determining the dynamic parameters of bridges built in Switzerland [2]. One of the results of research was the parameter $\mathrm{k}$ as a function of the bridge $\mathrm{L}$ span. The scope of examined bridge structures basically included all types of general attitude to medium and large spans. With compiled charts we can draw two conclusions: the value of $\mathrm{k}$ decreases with increasing span and concrete structures are stiffer than steel (including complex).

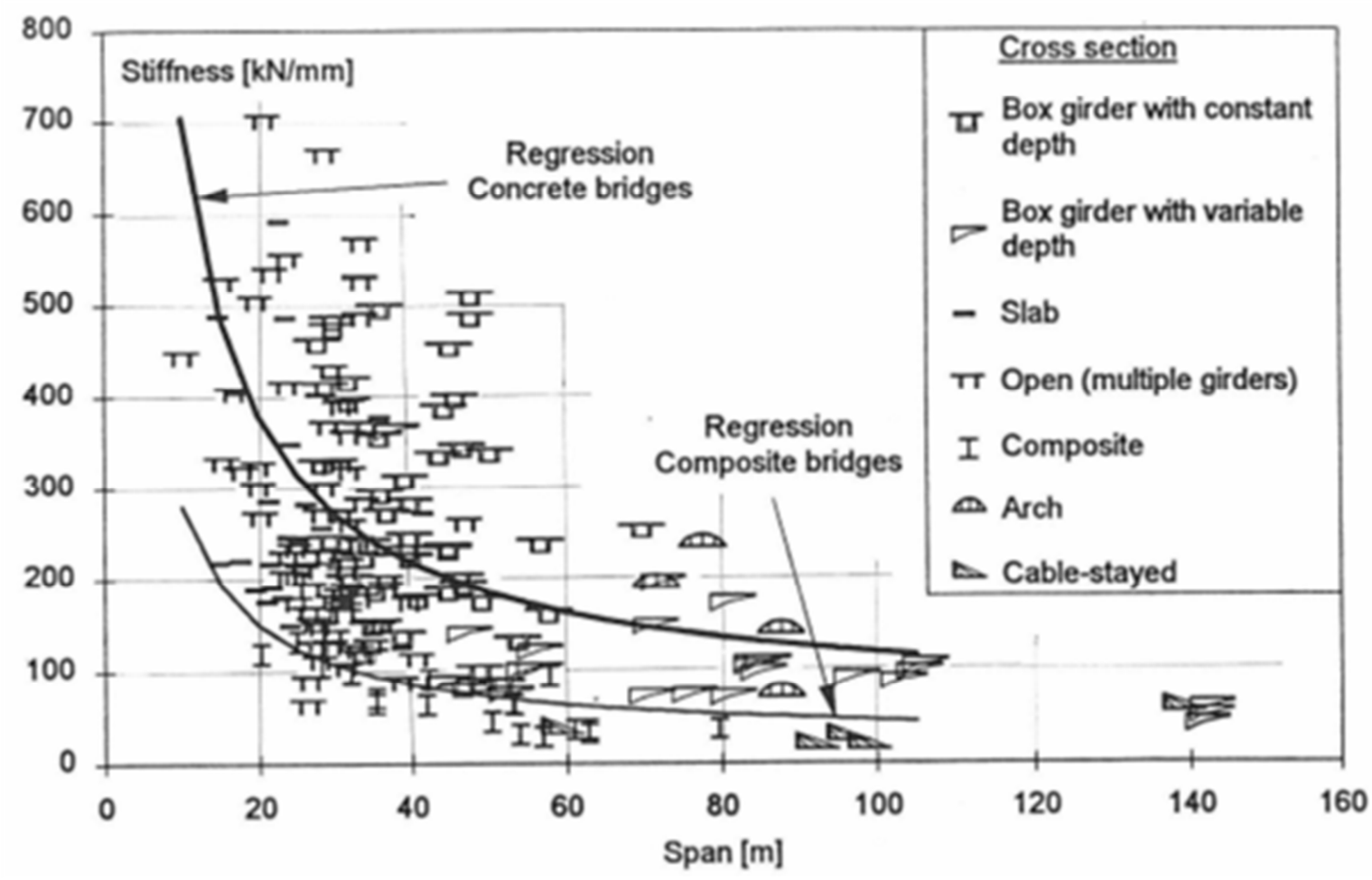

1. The results of road bridges researches in Switzerland [2]

Footbridge in bridge engineering have separate communication function. Their designs are extremely varied and schemes generally innovative. Fig. 2 shows selected results obtained also by the way of a dynamic test [3]. They belong to the group with the least stiffness and they are prone to dynamic excitations. The results shown in the graph are dispersed which may result from a small amount of data, but the trend is the same as in fig. 1 . 


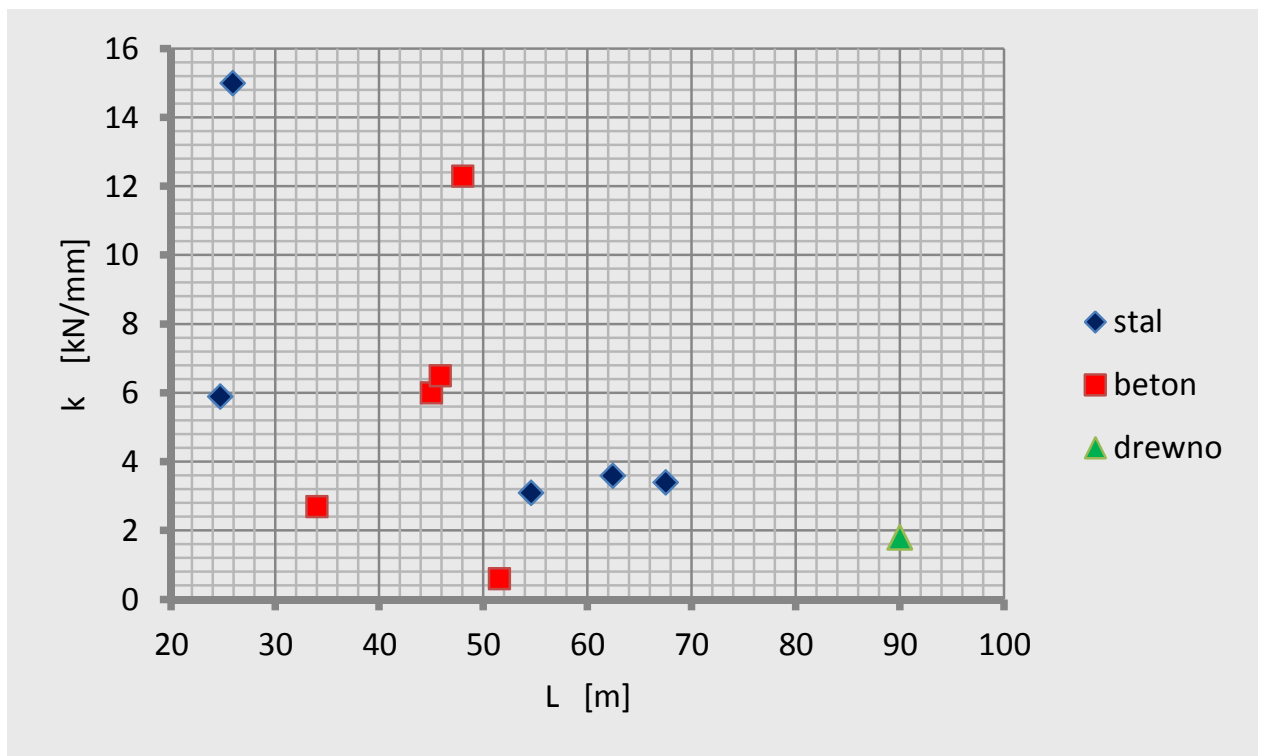

2. The stiffness of footbridges

The results addendum given in Fig. 1, when it comes to road bridges is small and medium-span analysis indicated in [5]. The object and purpose of the analysis in this elaboration is generalization of results and conclusions of the extension of road bridges on railway objects [12].

\section{The stiffness of bridges structure}

When we change the position of the unit concentrated force $\mathrm{P}$ is carried out along a straight line, as in bridges, chart deflection of this force is a line of impact as a function $\eta(x)$ shown in Fig. 3. By definition line impact deflection $\eta(x)$ is obtained in case of load force $P$ by changing the position along the $\mathrm{x}$ axis, the function of the deflection of the analyzed point (x) as in dependency

$$
w(x)=P \eta(x) \text {. }
$$

From a comparison of formulas (2) and (1) it is evident that the function of the stiffness $\mathrm{k}(\mathrm{x})$ is the reciprocal of the impact of diffraction lines, as in formula

$$
k(x)=\frac{1}{\eta(x)} \quad[\mathrm{kN} / \mathrm{mm}] .
$$

From equation (3) that the ordinate value of $\mathrm{k}(\mathrm{x})$ depend on the shape of influence function $\eta$ (x), and so geometry of the object and conditions of the support structure. The values of $\mathrm{k}$ are endless above supports (threshold effect $[4,12]$ ), whereas at the place of maximum of the function $\eta(\mathrm{x})$ is obtained by the minimum stiffness. Therefore the stiffness of object $\mathrm{k}$ is the inverse of the maximum elevation of influence function $\eta$, as shown in Fig. 3.

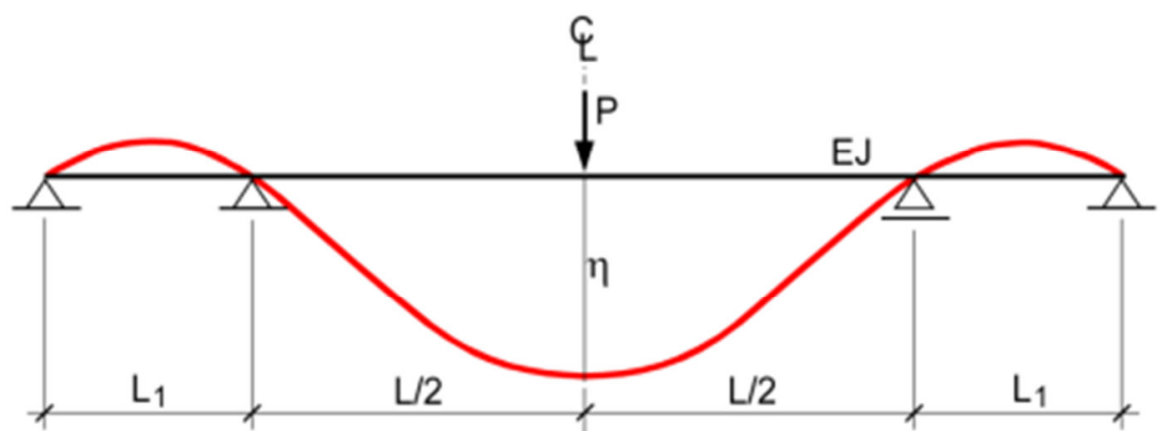

3. The line of beam diffraction impact in the middle of span 
According to Betti's theorem, ordinates functions of the impact of long-cut $\eta(x)$ are also deflections points in the structure (x) of the load force unit $\mathrm{P}$ in the reporting section, as shown in Fig. 3. It also follows the formula (2). Determine the $\mathrm{k}$ value is a search for the maximum deflection of the force moving the designated line - track railway bridge. Consequently, the task is limited to a simple solution - determining the deflection of the (x) along the railway track. In examined bridges this point is uniquely located - usually in the middle of the span.

In design phase and later during initial inspection of beam bridges schema is checked the rigidity of structure using the plot frame condition limit state, included in the dimensionless ratio

$$
\omega=\frac{w}{L}
$$

In formula (4) $\omega$ is the maximum deflection of the bridge, e.g. main girder, referring to the span element L. Indicator $\omega$ compared with the limit value defined in the recommendations (e.g. 1/600), according to the type of construction or structural element of the bridge and material used to its construction. Its value depends on the schema (the system) load. From a comparison of two indicators calculated on the basis of deflection $(\mathrm{k}$ and $\omega)$ it is evident that the stiffness is a parameter broader $[2,3,5,6]$.

\section{Railway arch bridge}

Arch bridges structures, are a subgroup of strut scheme, in which the vertical load on the horizontal components of the carriageway are formed support reactions. For a long time in this group appear arch bridges, made of e.g. brick or stone, as shown in Fig. 4a and the concrete structures. Currently used objects soil-coating the corrugated sheet, as shown in Fig. 4b show a lot common static features with the vaulted bridges.

a)

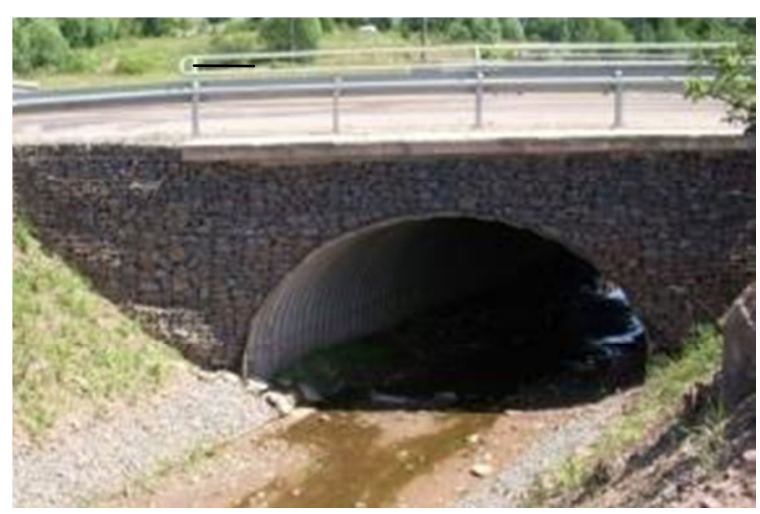

b)

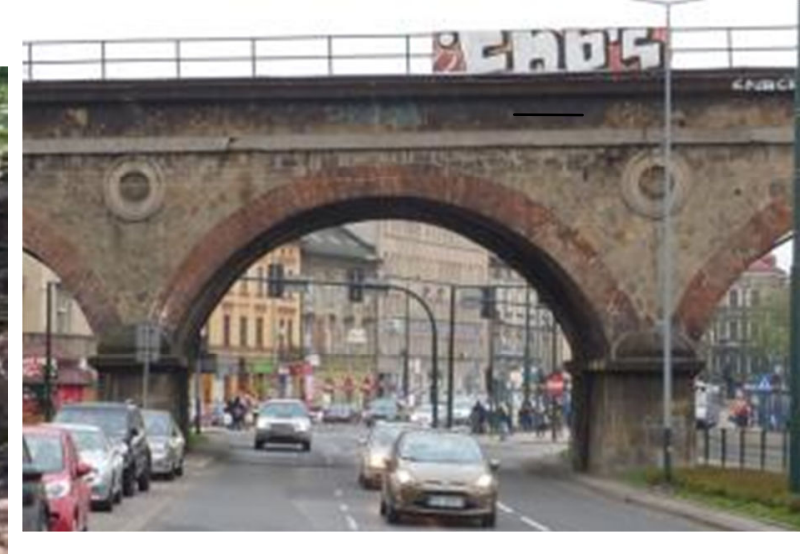

4. Arch bridges

a) soil-coating object; b) brick bridge

Table 1. Technical characteristics of examined objects

\begin{tabular}{|c|c|c|c|c|c|c|}
\hline Obiekt & $\begin{array}{c}\text { Konstrukcja } \\
\text { obiektu }\end{array}$ & $L[\mathrm{~m}]$ & $h[\mathrm{~m}]$ & $\begin{array}{c}w \\
{[\mathrm{~mm}]}\end{array}$ & $\begin{array}{c}k \\
{[\mathrm{kN} / \mathrm{mm}]}\end{array}$ & $\begin{array}{l}\omega=w / L \\
{[\mathrm{~mm} / \mathrm{m}]}\end{array}$ \\
\hline Prabuty & \multirow{2}{*}{$\begin{array}{l}\text { gruntowo- } \\
\text { powłokowa }\end{array}$} & 7,945 & 2,37 & 3,48 & 90,2 & 0,438 \\
\hline Świdnica & & 15,00 & 5,23 & 2,7 & 131,1 & 0,180 \\
\hline Milicz & murowana & 12,80 & 6,40 & 0,59 & 909,1 & 0,046 \\
\hline
\end{tabular}


Due to the basic participation of backfill and surface in load transfer structures in which stiffness of the object is best defined on the basis of research. Table 1 shows examples of the measurement results of both types of facilities [5, 6]. Study of these objects show significant differences in their stiffness. Therefore the principle of treatment is confirmed as a massive brick vaults, unlike ground-coating corrugated sheet - susceptible.

\section{Main girders of steel girder bridges}

The most common static scheme of railway bridges is freely supported beam [5]. Movable load used for design bridge elements is for a long time (PN-85 / S-10030) and currently (EN-1921-2) scheme UIC 71, shown in fig. 5. The forces in this scheme depends on the load class and exactly the Plot frame multiplier $\alpha \mathrm{k}$. Due to the different layout (concentrated forces $\mathrm{P}$ and striped $\mathrm{p}$ ) of deflection in the middle of the span is calculated from an approximate (but sufficient accuracy [5]) based on

$$
w=\frac{M \cdot L^{2}}{10 E I}
$$

and the bending moment in the middle of the main span girder when set forces as shown in fig. 5, without taking into account the dynamic interaction

$$
M=10 \alpha_{k}\left[25(L-3,2)+(L-6,4)^{2}+1,6^{2}\right] \quad[\mathrm{kN} / \mathrm{m}] .
$$

In the formula (5) EI is stiffness of the girder due to the bending and the span $\mathrm{L}$.

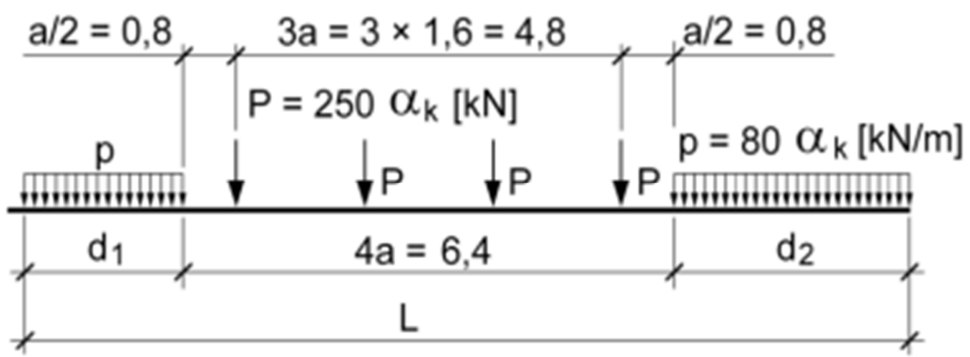

5. Scheme of railway bridges forces UIC 71

On the basis of plot frame boundary condition deflection as in (4), usually adopted as $\omega=\omega=1 / 600$ and 1/800 may be calculated e.g. the formula (5) flexural stiffness of the girder

$$
E I=\frac{M \cdot L}{10 \cdot \omega}
$$

and directly from (1) and (6) normalized stiffness object (girder) as

$$
k_{U I C}=48 \frac{E I}{L^{3}}=\frac{48 \alpha_{k}}{10 \omega L}\left[25(L-3,2)+(L-6,4)^{2}+1,6^{2}\right] \quad[\mathrm{kN} / \mathrm{mm}] .
$$

In (8) was applied the formula for beam deflection schema freely supported loaded force unit in the middle of the span

$$
w=\frac{L^{3}}{48 E I} \quad .
$$

Fig. 6 shows graphs kUIC (L) obtained from (8) on admission $\alpha \mathrm{k}=1.21$. A comparison of the results obtained in the road bridges (fig. 1) and rail (fig. 6) shows that the stiffness of railway facilities may be much smaller than the road bridges. In the monograph [5] there are given many examples of concrete road bridges including monolithic and prefabricated beams confirming the attention. However, the categorical formulation of the overall proposal for the stiffness of road and railway bridges requires more data. 
$\mathrm{K}$ values of fig. 6 are similar to the results obtained in the premises of soil-coating [6] shown in table. 1. Although a significant difference in the construction of both types of structures because of their stiffness, they can be placed in the same group.

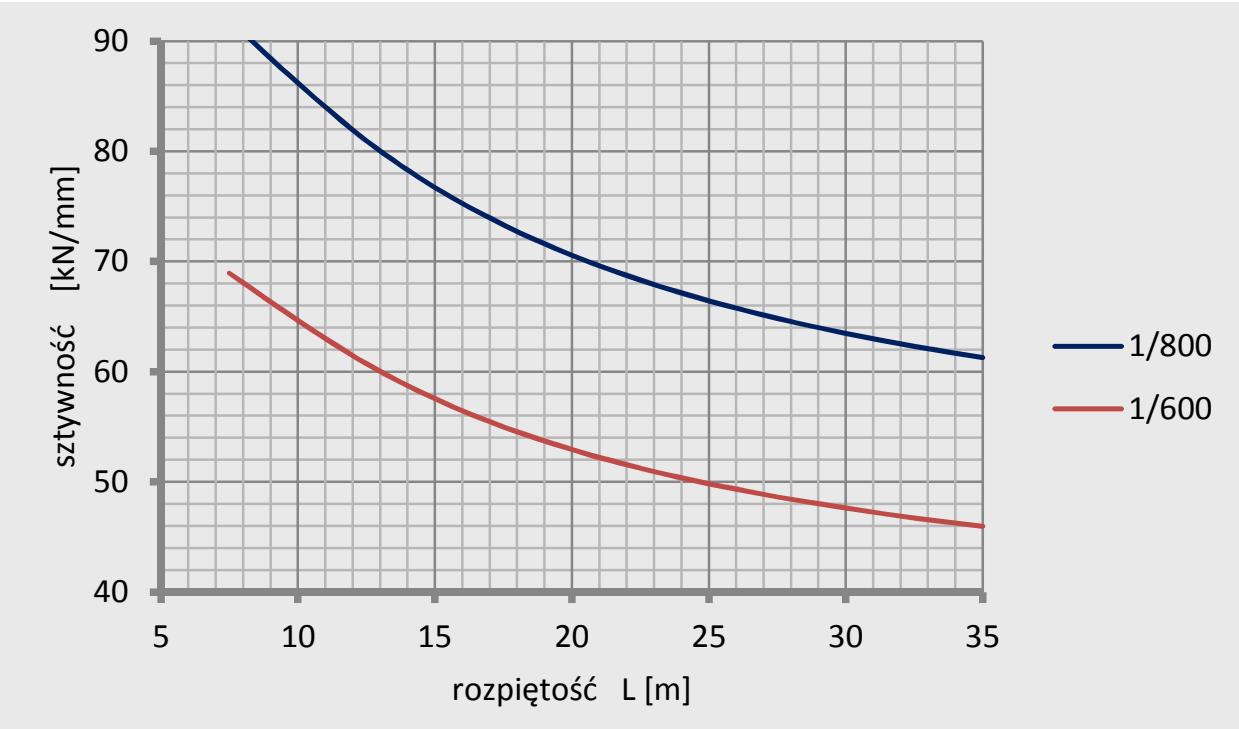

6. Standardized stiffness of steel railway bridges depending on the indicator $\omega$

\section{Longitudinal members railway bridges with the open surface}

Longitudinal members steel bridges made of truss or plate grider in the rail surface with surface on bridge sleeper are designed with the adoption of the freely supported beam scheme with a load, as shown in fig. 5. Spans of these elements are not dependent on L span length and are equal of positioning transoms t. Usually value of $t<7 \mathrm{~m}$, are comparable to small railway bridges span $L$.

Loads of these elements are relatively large. In the load diagram shown in fig. 5 an important role play concentrated forces P. In case of short longitudinal members, usually one concentrated force is load, hence the calculated normalized stiffness is calculated as

$$
k_{U I C}=\frac{\alpha_{k} P}{\omega \cdot t}
$$

When the length of longitudinal member allows to set the two axes with a pitch, and the formula (10) takes the form

$$
k_{U I C}=\frac{\alpha_{k} P}{32 \omega \cdot t}\left(4-\alpha^{2}\right)\left[2(2-\alpha)(6-\alpha)-(2+\alpha)^{2}\right],
$$

where $\alpha=\mathrm{a} / \mathrm{t}$, however, as shown in fig. $5 \mathrm{a}=1.6 \mathrm{~m}$. When creating the pattern (11) was adopted the unbalanced position of the two forces $P$, giving a maximum bending moment [5]. Deflection in this configuration of the load is calculated at the point at which there Mmax.

In case of load three concentrated forces, arrangement is symmetrical relative to the spans' center. Therefore, when $\mathrm{x}=\mathrm{t} / 2$ is obtained as the relation

$$
k_{U I C}=\frac{\alpha_{k} P}{\omega \cdot t}\left\{1+(1-2 \alpha)\left[3-(1-2 \alpha)^{2}\right]\right\},
$$

When $\mathrm{t}>4.8 \mathrm{~m}$ it takes into account the load spread on the right side of beam. If the span $\mathrm{p}>$ $6.4 \mathrm{~m}$ on the beam are now four concentrated forces with a force spread out on one side. This arrangement is made to load deflection calculation, hence the procedure is analogous to that of the main girder, included in (8). In case of the largest stringers span, their normalized stiffness is calculated by the formula 


$$
k_{U I C}=\frac{6 \alpha_{k} P}{5 \omega \cdot t}\left[4(1-2 \alpha)+t \frac{25}{16}(1-3 \alpha)^{2}\right] .
$$

Fig. 7a shows the functions diagrams $(\mathrm{t})$ when $\alpha \mathrm{k}=1.21$. This diagram is similar to one, shown in fig. 6 , as in case of main girder, stiffness is bigger.

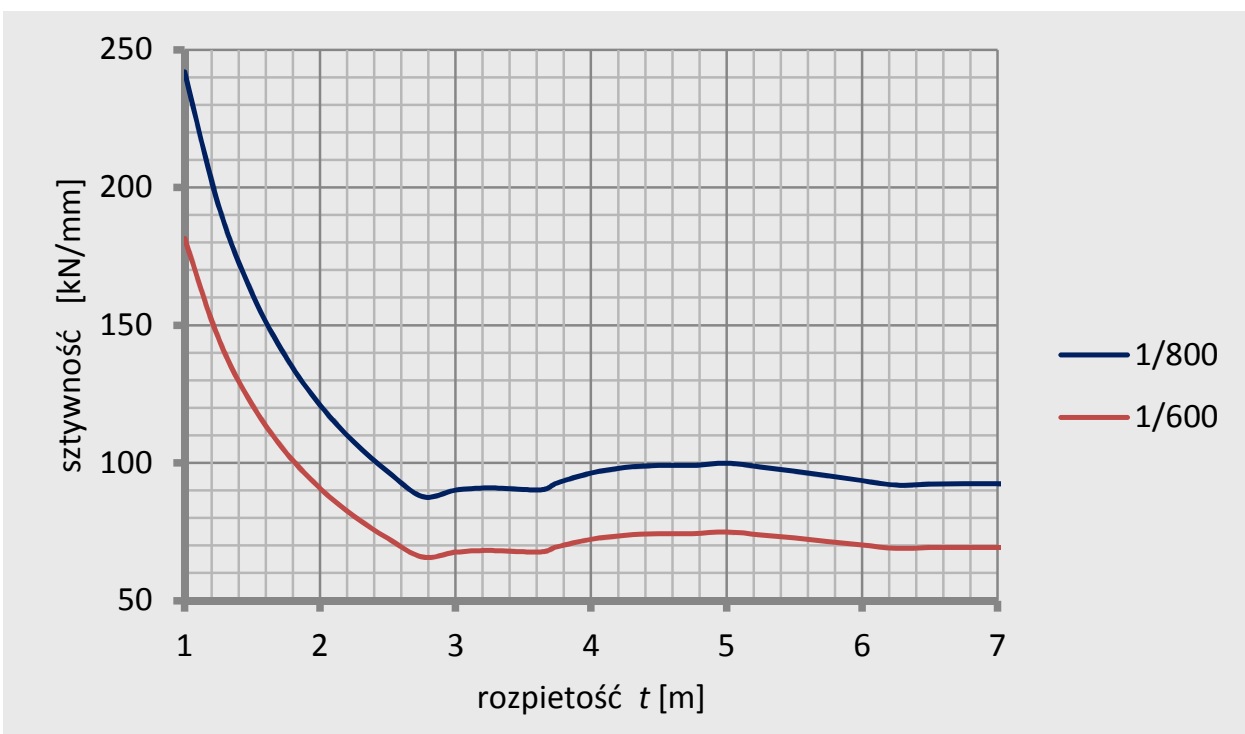

7. Standardized longitudinal member stiffness of railway bridges depending on the indicator $\omega$

When the geometric characteristics of stringers are determined on basis of data from new buildings, the stiffness can be calculated based on their span and the moment of inertia of two, twin elements 2I. Therefore, the formula

$$
k=48 \frac{2 E I}{t^{3}}
$$

when $\mathrm{E}=205 \cdot 106 \mathrm{kN} / \mathrm{m} 2$. Fig. 8 shows the results of inventory, mainly the old railway bridges. Stringers' stiffness of railway bridges are similar to defined values by recommendations specified by standards for the deflection shown in the graphs fig. 7 .

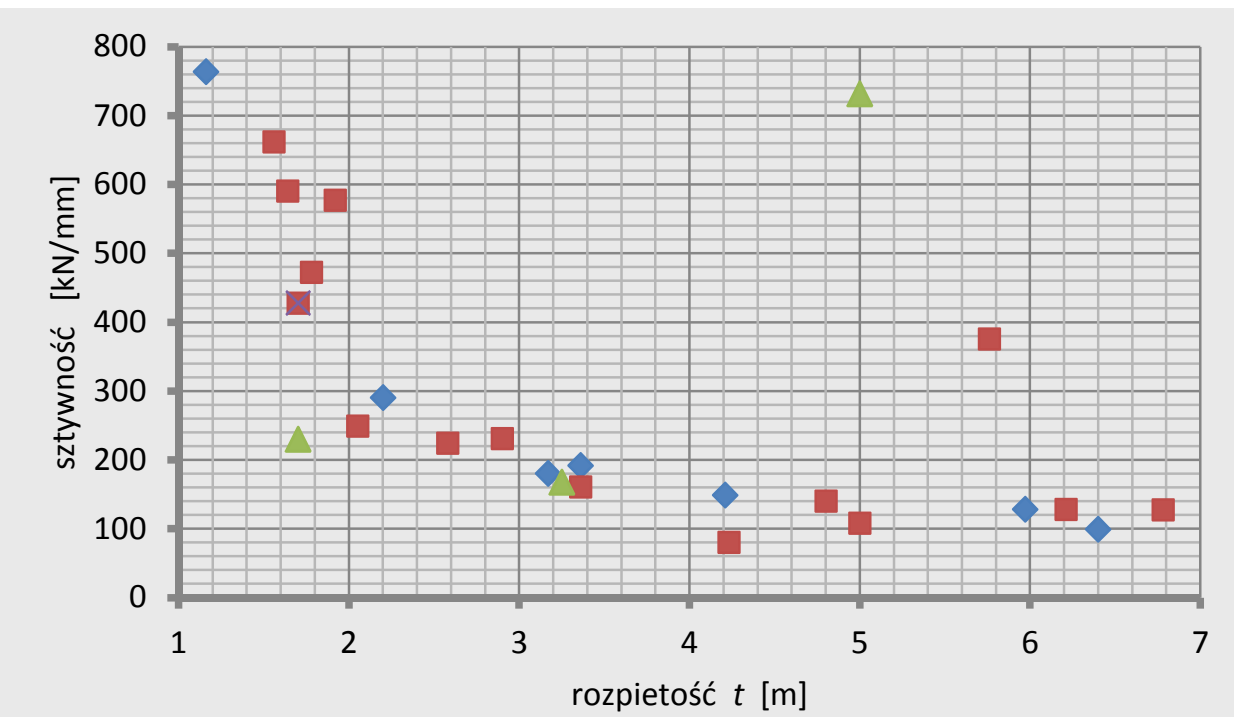

8. Longitudinal member stiffness of railway bridges with surface on bridge sleepers 


\section{Summary}

For the classification of objects with a communication function to the group of solid (rigid) and slender (susceptible) useful is indicator k. It can be applied to the bridges of various construction as in figures $1,2,4$. The values of $\mathrm{k}$ can be obtained by calculation, and also of research facility operating under load (including equipment cooperation with construction). In elaboration results, we can see classical division because of the k-values, the solid and limp objects due to the used material. In case of analyzed type of bridge, its stiffness is connected with span - small bridges, are inherently stiffer than ones with longer lengths. The results of stiffness analysis in bridges is visible on the general division depending on usage: road objects, railway footbridge. Larger group of analyzed objects are shown in [5, 6].

We can see in railway bridges, classification according to decreasing stiffness: arch bridges, ground-coating buildings, beam bridges (transmural). Beam stiffness can be greater than stiffness of main girders in classical truss and beam bridges.

\section{Source materials}

[1] Bryja D., Hołubowski R.: Losowe zmiany sztywności podsypki w analizie drgań zespolonego mostu kolejowego. Przegląd Komunikacyjny, 2013, 12, s. 30-35.

[2] Burdet O., Corthay S.: Static and dynamic load testing of Swiss bridges. International Bridge Conference Warsaw '94. Proceedings. June 20-22, 1994. Vol. 2. Analytical evaluation of bridges bridge management system. Warszawa: IBDiM 1994 p. 13-22.

[3] Hawryszków P.: Analiza cech dynamicznych kładek dla pieszych, ocena wrażliwości dynamicznej oraz komfortu użytkowania. Raport serii PRE nr 6/2009, praca doktorska, Wrocław, czerwiec 2009.

[4] Klasztorny M.: Dynamika mostów belkowych obciążonych pociągami szybkobieżnymi. WNT, Warszawa 2005

[5] Machelski C.: Ruchome obciążenia obiektów mostowych. Dolnośląskie Wydawnictwo Edukacyjne, Wrocław 2015.

[6] Machelski C.: Stiffness of railway soil-steel structures. Studia Geotechnika et Mechanica. No 4/2015 p. 29-36.

[7] Mackiewicz P.: Ocena wpływu wybranego wzmocnienia podłoża gruntowego na trwałość konstrukcji nawierzchni drogowej z uwzględnieniem kryteriów deformacji podłoża gruntowego. Przegląd Komunikacyjny, 2014, R. 69, nr 5, s. 27-30

[8] Mackiewicz P.: Finite-element analysis of stress concentration around dowel bars in jointed plain concrete pavement. Journal of Transportation Engineering, 2015, vol. 141, nr 6

[9] Mackiewicz P., Szydło A.: Oddziaływanie drogowej płyty betonowej na podbudowę i podłoże w warunkach zmiennej temperatury dobowej. Przegląd Komunikacyjny, 2015, R. 70, nr 3, s. 19-24

[10] Nagórski R.: Mechanika nawierzchni drogowych w zarysie. PWN, Warszawa 2014.

[11]Rigueiro C., Rebelo C., da Silva L.S.: Influence of ballast models in the dynamic response of railway viaducts. Journal of Sound and Vibration, 2010, 329 pp. 3030-3040.

[12] Szcześniak W.: Wybrane zagadnienia kolejowe. Wzajemne oddziaływania w układzie pojazd-tor kolejowy-podtorze-podłoże gruntowe. Prace naukowe PW. Budownictwo z. 129, Warszawa 1995.

[13] Toth J., Ruge P.: Spectral assessment of mesh adaptations for the analysis of the dynamical longitudinal behavior of railway bridges. Archive of Applied Mechanics 2001, 71 pp. 453-462.

[14] Qu W. L. et al.: Intelligent control for braking-inducted longitudinal vibration responses of floating-type railway bridge. Smart materials and Structures 2009, 18, pp. 1-20. 